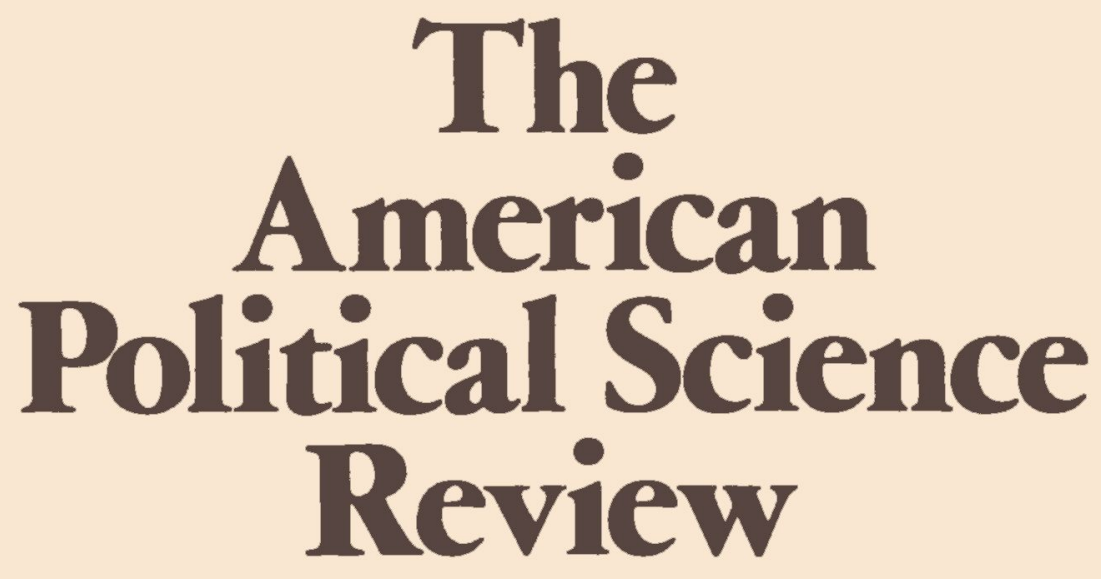

Published Quarterly by The American Political Science Association 


\section{Our texts are fundamental}

\section{All new! \\ Anderson/Murray/Farley TEXAS POLITICS}

An Introduction, Fourtb Edition

355 pages. Instructor's Manual.

\section{Gray/Michalak AMERICAN FOREIGN POLICY SINCE DETENTE \\ 228 pages.}

Nigro/Nigro

MODERN PUBLIC

ADMINISTRATION

Slatb Edition

416 pages. Instructor's Manual.

Elazar

\section{AMERICAN FEDERALISM}

A Vew from the States, Ibtrd Edition

288 pages/tent.

\section{Jones}

CONDUCTING POLITICAL

\section{RESEARCH}

Second Edttion

288 pages/tent.

To request examination coples, write to Suite 3D, Harper \& Row, 10 East 53d Street, New York, N.Y. 10022. Please include course title, enrollment, and present text.

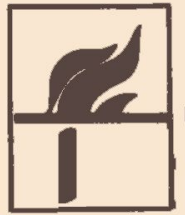




\section{The American Political Science Review}

\section{CONTENTS}

The Heresthetics of Constitution-Making: The Presidency in 1787,

with Comments on Determinism and Rational Choice .......... William H. Riker

Changes in the Vote Margins for Congressional Candidates:

A Specification of Historical Trends ........ James C. Garand \& Donald A. Gross

Free Association and the Theory of Proportional

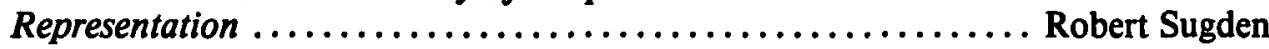

Advocacy, Interpretation, and Influence in the U.S. Congress ..... Richard A. Smith

Interest Representation: The Dominance of Institutions . ...... . Robert H. Salisbury

Nationalization of the American Electorate .... . William Claggett, William Flanigan, \& Nancy Zingale

In Search of the Center of European Party Systems ............ Hans Daalder

The Constituency Service Basis of the Personal Vote for U.S.

Representatives and British Members of

Parliament ............ Bruce E. Cain, John A. Ferejohn, \& Morris P. Fiorina

Bureaucrats and Politicians in Policymaking:

The Case of Japan ................. Michio Muramatsu \& Ellis S. Krauss

Do Cooperators Exit More Readily than Defectors? ............ John M. Orbell,

Peregrine Schwartz-Shea, \& Randy T. Simmons

A Method of Estimating the Personal Ideology of

Political Representatives ............. Richard A. Carson \& Joe Oppenheimer

The Particulars of a Universal Politics:

Hegel's Adaptation of Montesquieu's Typology ............. Michael Mosher

The Relative Influence of European Writers on

Late Eighteenth-Century American Political Thought .......... Donald S. Lutz

Communications

Book Reviews

American Government and Politics $\ldots \ldots \ldots \ldots \ldots \ldots \ldots \ldots \ldots \ldots \ldots \ldots$

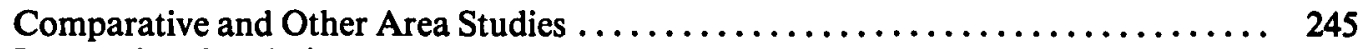

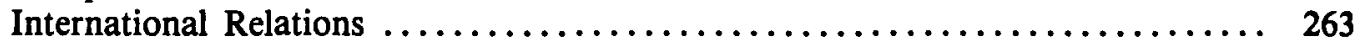

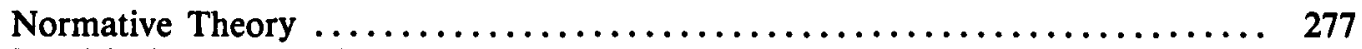

Empirical Theory and Methodology $\ldots \ldots \ldots \ldots \ldots \ldots \ldots \ldots \ldots \ldots \ldots \ldots \ldots$

The American Political Science Review appears in March, June, September, and December of each year. It is published by the American Political Science Association, 1527 New Hampshire Avenue, N.W., Washington, D.C. 20036, and sent to all members. Dues: Regular members with income: under \$20,000, \$40;\$20,000-\$29,999, \$50; $\$ 30,000-\$ 39,999, \$ 65 ; \$ 40,000$ and over, \$75; Student Members (limited to 5 years), \$15; Retired Members, \$20; Life Members, \$1,000; Institutional Members, \$75. Dues allocated for a subscription to the APSR: \$10. Changes of address sent to the Membership Secretary of the APSA. Postmaster: Please send notification regarding undelivered journals to address above. Second-class postage paid at Washington, D.C. and at additional mailing offices. Copyright (C) 1984 by The American Political Science Association (ISSN-003-0554). 


\section{BOOK REVIEWS}

\section{American Government and Politics}

Abramson, Paul R. Political Attitudes in America:

Formation and Change .............................. Norman $R$. Luttbeg

Adams, William C., ed. Television Coverage of the

1980 Presidential Campaign ............................. Margaret K. Latimer

Alston, Richard M. The Individual vs. the Public Interest:

Political Ideology and National Forest Policy .................... Craig Ramsay

Barber, Bernard. The Logic and Limits of Trust ................ Robert A. Heineman

Barfield, Claude E. Science Policy from Ford to Reagan:

Change and Continuity ............................... Richard P. Hiskes

Beyle, Thad L., \& Lynn R. Muchmore. Being Governor:

The View from the Office ............................. James D. Nowlan

Bowles, Samuel, David M. Gordon, \& Thomas E. Weisskopf.

Beyond the Wasteland: A Democratic Alternative to

Economic Decline .................................... Leon Grunberg

Brenner, Philip. The Limits and Possibilities of Congress .............. Steven A. Shull

Brown, Lawrence D. Politics and Health Care Organization:

HMOs as Federal Policy ................................ Richard D. Willis

Buss, Terry F., \& F. Stevens Redburn. Shutdown in Youngstown:

Public Policy for Mass Unemployment ..................... Clarence N. Stone

Carp, Robert A., \& C. K. Rowland. Policymaking and Politics

in the Federal District Courts ............................ Charles M. Lamb

Cigler, Allan J., \& Burdett A. Loomis, eds.

Interest Group Politics ................................... John T. Tierney

Clarke, Peter, \& Susan H. Evans. Covering Campaigns:

Journalism in Congressional Elections .................... Charles M. Tidmarch

Conover, Pamela Johnston, \& Virginia Gray. Feminism and

the New Right: Conflict over the American Family ................. Janet K. Boles

Davis, James W. National Conventions in an Age of

Party Reform ..................................... Patrick A. Pierce

D'Emilio, John. Sexual Politics, Sexual Communities:

The Making of a Homosexual Minority in the United

States, $1940-1970$

David C. Colby

de Sola Pool, Ithiel. Technologies of Freedom $\ldots \ldots \ldots \ldots \ldots \ldots \ldots \ldots \ldots \ldots \ldots \ldots$. Phyllis Zagano

Fainstein, Susan S. et al., eds. Restructuring the City:

The Political Economy of Urban Redevelopment ................. Charles E. Ellison

Falik, Marilyn. Ideology and Abortion Policy Politics.

Steiner, Gilbert Y., ed. The Abortion Dispute and the American System

Gormley, William T., Jr. The Politics of Public Utility

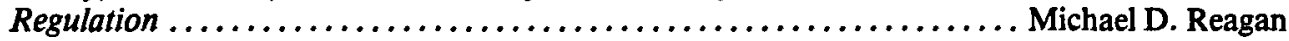

Graber, Doris A., ed. The President and the Public ................ Alana Northrop

Grenzke, Janet Miller. Influence, Change, and the

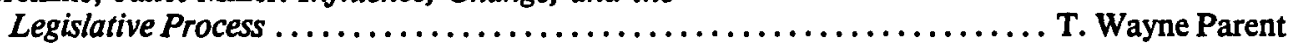

Heinz, Anne, Herbert Jacob, \& Robet L. Lineberry, eds.

Crime in City Politics ............................... Susette M. Talarico

Kaplan, John. The Hardest Drug: Heroin and Public Policy ............ Rodney A. Grunes

Kline, John M. State Government Influence in

U.S. International Economic Policy ......................... James E. Jarrett

Lake, Laura M. Environmental Regulation: The Political

Effects of Implementation ................................ Henry B. Sirgo

Larson, Gary O. The Reluctant Patron: The United States

Government and the Arts, 1943-1965.

Margaret Jane Wyszomirski

Lefcoe, George, ed. Urban Land Policy for the 1980s:

The Message for State and Local Government .

. Duane Windsor 
Marling, Karal Ann. Wall-to-Wall America: A Cultural

History of Post-Office Murals in the Great Depression

Kevin V. Mulcahy

McAdam, Doug. Political Process and the Development of

Black Insurgency 1930-1970

Dianne M. Pinderhughes

McLure, Charles E., Jr., \& Peter Mieszkowski, eds. Fiscal

Federalism and the Taxation of Natural Resources ............... Kathleen O. Jackson

Musolf, Lloyd. Undle Sam's Private, Profitseeking

Corporations ..................................... Brinton Milward

Neiman, Max, \& Barbara J. Burt, eds. The Social Constraints

on Energy-Policy Implementation ......................... David D. Dabelko

Palmer, John L., \& Isabel V. Sawhill, eds. The Reagan Experiment ...

Margaret V. Moody

Regens, James L., Robert W. Rycroft, \& Gregory A. Daneke, eds. Energy and the Western United States:

Politics and Development Daniel Sloan

Rosenbloom, David H. Public Administration and Law:

Bench v. Bureau in the United States .......................... John A. Rohr

Schuck, Peter H. Suing Government: Citizen Remedies

for Official Wrongs ...................................... Bert C. Buzan

Sinclair, Barbara. Congressional Realignment, 1925-1978 ............... Darrell M. West

Stone, Alan, \& Edward J. Harpham, eds. The Political Economy of Public Policy

L. L. Wade

Thomas, Ann Van Wynen, \& A. J. Thomas, Jr. The

War-Making Powers of the President: Constitutional and

International Law Aspects ................................ Michael A. Genovese

Tucker, Robert W., \& David C. Hendrickson. The Fall of the

First British Empire: Origins of the War of

American Independence ............................. John S. Vanderoef

Turner, Michael. The Vice President as Policy Maker:

Rockefeller in the Ford White House ................... Raymond L. Chambers

Whalen, Charles W., Jr. The House and Foreign Policy ................... Jerel A. Rosati

Woody, Bette. Managing Crisis Cities: The New Black

Leadership and the Politics of Resource Allocation ................. Luther F. Carter

Zeisel, Hans. The Limits of Law Enforcement ................... James E. Robertson

Zimmerman, Joseph F. State-Local Relations:

A Partnership Approach

Robert K. Whelan

Comparative and Other Area Studies

Bahl, Roy, \& Barbara D. Miller, eds. Local Government

Finance in the Third World: A Case Study of the

Philippines

Ross Marlay

Bodganor, Vernon, ed. Liberal Party Politics.

Kavanagh, Dennis, ed. The Politics of the Labour Party .................. Peter Mair

Breslauer, Geroge W. Khrushchev and Brezhnev as Leaders:

Building Authority in Soviet Politics ...................... Carey Cavanaugh

Cartwright, John. Political Leadership in Africa ................. Gerald L. Gordon

Dwivedi; O. P., ed. The Administrative State in Canada:

Essays for J. E. Hodgetts ............................. Barry Cooper

Johnston, R. J. Geography and the State:

An Essay in Political Geography

Ladis K. D. Kristof

Logue, John. Socialism and Abundance: Radical

Socialism in the Danish Welfare State ........................... Roger Wall

Madgwick, Peter, \& Richard Rose, eds. The Territorial

Dimension in United Kingdom Politics . .

John Kurt Jacobsen

McClintock, Cynthia, \& Abraham F. Lowenthal, eds.

The Peruvian Experiment Reconsidered ..................... Jonathan Hartlyn

Okimoto, Daniel I., ed. Japan's Economy: Coping with

Change in the International Environment

Tsuneo Akaha 
Powell, G. Bingham, Jr. Contemporary Democracies:

Participation, Stability and Violence ............................ Mark Lichbach

Randall, Vicky. Women and Politics ............................ Eileen L. McDonagh

Rigsby, T. H., \& Ferenc Feher, eds. Political

Legitimation in Communist States ...................... Bohdan Harasymiw

Ritter, Archibald R. M., \& David H. Pollock, eds.

Latin American Prospects for the 1980s: Equity,

Democratization, and Development

Elisha Greifer

Rose, Richard, \& Edward Page, eds. Fiscal Stress in Cities ................... Irene Rubin

Sandford, Gregory W. From Hitler to Ulbricht:

The Communist Reconstruction of East Germany 1945-46 ........... Richard L. Merritt

Stanbury, W. T., \& Fred Thompson, eds. Managing Public

Enterprises ...

James E. Swiss

Stookey, Robert W. South Yemen: A Marxist Republic

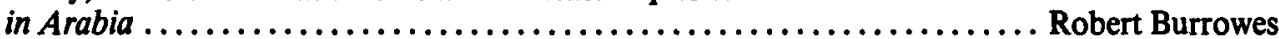

Tummala, Krishna K., ed. Administrative Systems Abroad ........... Richard E. Hartwig

Yeager, Rodger. Tanzania: An African Experiment ................ Harvey Glickman

Zartman, I. William, ed. The Political Economy of Nigeria .............. Robert Melson

\section{International Relations}

Barnaby, Frank, \& Geoffrey Thomas, eds. The Nuclear Arms Race: Control or Catastrophe?

Kincade, William H., \& Christoph Bertram, eds.

Nuclear Proliferation in the 1980s: Perspectives and

Proposals .............................................. Philip W. Dyer

Beres, Louis Rene. Mimicking Sisyphus: America's

Countervailing Nuclear Strategy .......................... Anne H. Cahn

Christol, Carl Q. The Modern International Law of

Outer Space

Eric J. Novotny

Cohen, Stephen D., \& Ronald I. Meltzer. United States

International Economic Policy in Action: Diversity of

Decision Making ................................... John S. Odell

Crabb, Cecil V., Jr. The Doctrines of American Foreign

Policy: Their Meaning, Role and Future.

Richard B. Finnegan

Feldman, Shai. Israeli Nuclear Deterrence:

A Strategy for the 1980s.

Paul F. Power

Hagan, Lawrence S., ed. The Crisis in Western Security .............. William K. Domke

Holloway, David. The Soviet Union and the Arms Race ............... John M. Carfora

Hopple, Gerald W., ed. Biopolitics, Political Psychology and

International Politics: Towards a New Discipline ............... William D. Richardson

Hosmer, Stephen T., \& Thomas W. Wolfe. Soviet Policy and

Practice toward Third-World Conflicts ......................... Harry Ododa

Murphy, John F. The United Nations and the Control of

International Violence: A Legal and Political Analysis ............... Keith S. Petersen

O'Connell, D. P.; ed. by I. A. Shearer. The International

Law of the Sea, vol. $1 \ldots \ldots \ldots \ldots \ldots \ldots \ldots \ldots \ldots \ldots$ Lauriston R. King

Towle, Philip. Arms Control and East-West Relations ................ Robert C. Gray

Vernon, Raymond. Two Hungry Giants: The United States and Japan in the Quest for Oil and Ores ....................... John R. McIntyre

Zartman, I. William, \& Maureen R. Berman. The

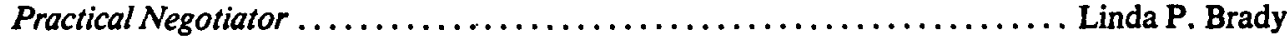

Normative Theory

Arendt, Hannah; ed. by Ronald Beiner. Lectures on Kant's Political Philosophy.

Riley, Patrick. Kant's Political Philosophy Donald J. Maletz 
Blumenberg, Hans; trans. by Robert Wallace.

The Legitimacy of the Modern Age ....................... Stephen Holmes

Bok, Sissela. Secrets: On the Ethics of Concealment

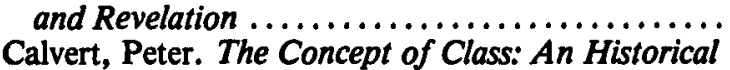

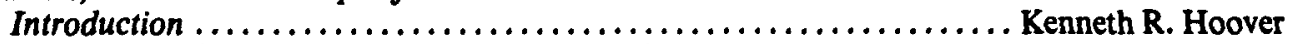
John P. Burke 279

Canavan, Francis, ed. The Ethical Dimension of Political

Life: Essays in Honor of John H. Hallowell .................... Steven D. Ealy

Charvet, John. Feminism ............................ Mary Anne Cavicchi

Darby, Tom. The Feast: Meditations on Politics and Time .............. Steven B. Smith

Fishkin, James S. Justice, Equal Opportunity, and

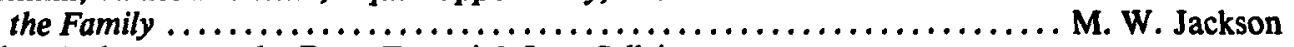

Kiss, Arthur; trans. by Peter Tamasi \& Ivan Sellei.

Marxism and Democracy .............................. Ronald J. Hunt

Leigh, R. A., ed. Rousseau after Two Hundred Years:

Proceedings of the Cambridge Bicentennial Colloquium

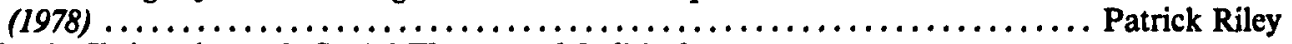

Lloyd, Christopher, ed. Social Theory and Political

Practice ............................................... Susan Hekman

Nisbet, Robert. Prejudices: A Philosophical Dictionary ............ W: Wesley McDonald

Summers, Robert Samuel. Instrumentalism and

American Legal Theory ................................. Bradford Wilson

Vedung, Evert. Political Reasoning .........................William J. Williams

Walzer, Michael. Spheres of Justice: $A$ Defense of Pluralism and Equality

Ronald Kahn

Weinstein, Michael A. The Wilderness and the City: American Classical Philosophy as a Moral Quest ................... Mark Reader

Empirical Theory and Methodology

Apostle, Richard A., et al. The Anatomy of

Racial Attitudes .

Brewer, Garry D., \& Peter deLeon. The Foundations of Policy Analysis.

Paris, David C., \& James F. Reynolds. The Logic of Policy Inquiry .................................... Francis W. Hoole

Roemer, John E. A General Theory of Exploitation and Class Margaret Levi

Schwarz, Brita, Uno Svedin, \& Bjorn Wittrock. Methods in Futures Studies: Problems and Applications Mark R. Daniels

Weinstein, Brian. The Civic Tongue: Political Consequences of Language Choices 


\title{
The American Political Science Association
}

\author{
1527 New Hampshire Avenue, N.W., Washington, D.C. 20036
}

PRESIDENT: Philip E. Converse, University of Michigan; PRESIDENT-ELECT: Richard F. Fenno, Jr., University of Rochester; VICE PRESIDENTS: Ada W. Finifter, Michigan State University; James G. March, Stanford University; James W. Prothro, University of North Carolina; SECRETARY: Arend Lijphart, University of California, San Diego; TREASURER: Susan Welch, University of Nebraska, Lincoln; EXECUTIVE DIRECTOR: Thomas E. Mann; PROGRAM CHAIRPERSON: Doris A. Graber, University of Illinois at Chicago; MANAGING EDITOR, APSR: Dina A. Zinnes, University of Illinois.

COUNCIL (Above-named officers ex officiis), 1982-84: Twiley Barker, University of Illinois at Chicago; Bruce Bueno de Mesquita, University of Rochester; Walter Dean Burnham, Massachusetts Institute of Technology; Suzanne Garment, Wall Street Journal; Ole R. Holsti, Duke University; Gerald H. Kramer, California Institute of Technology; Michael Walzer, Institute for Advanced Study; Philip Williams, Nuffield College, Oxford University. 1983-85: Charles W. Anderson, University of Wisconsin at Madison; Morris P. Fiorina, Harvard University; Helen Ingram, University of Arizona; Nannerl Keohane, Wellesley College; Michael B. Preston, University of Illinois at Urbana-Champaign; Arlene W. Saxonhouse, University of Michigan; W. Phillips Shiveley, University of Minnesota; Gerald Wright, Indiana University.

\section{The American Political Science Review \\ Department of Political Science, University of Illinois at Urbana-Champaign, Urbana, Illinois 61801}

EDITORIAL BOARD: Dina A. Zinnes, Managing Editor, University of Illinois at Urbana-Champaign; John H. Aldrich, University of Minnesota; G. Robert Boynton, University of Iowa; Naomi Caiden, California State College; David Cameron, Yale University; John Ferejohn, Center for Advanced Studies; John R. Freeman, Massachusetts Institute of Technology; Sheldon Goldman, University of Massachusetts; Russell L. Hanson, Indiana University; Ruth Jones, Arizona State University; James H. Kuklinski, University of Illinois at Urbana-Champaign; Mary P. Nichols, Catholic University of America; Jerrold Rusk, University of Arizona; Barbara Salert, Washington University.

BOOK REVIEW EDITORIAL BOARD; Steven Thomas Seitz, Book Review Editor, University of Illinois at Urbana-Champaign; Ina A. Jeffery, Florida A\&M University; William C. Mitchell, University of Oregon; Lawrence B. Mohr, University of Michigan; W. Phillips Shively, University of Minnesota.

MANUSCRIPT EDITORS: Mary L. Giles, Merle L. Levy.

EDITORIAL INTERN: Bradley Gitz.

TECHNICAL ASSISTANTS: John C. Sandry, Cory H. Goldberg.

INDEXING: Articles and notes appearing in the Review before the June 1953 issue were indexed in The Reader's Guide to Periodical Literature. Current issues are indexed by The International Political Science Abstracts, the United States Political Science Documents, and the Social Sciences and Humanities Index. Microfilm of the Review, beginning with Volume 1, may be obtained from University Microfilms, 300 North Zeeb Road, Ann Arbor, Michigan 48106. A Cumulative Index of the Review, Volumes 1-62, 1906-1968, may also be obtained from University Microfilms. Articles appearing in the Review are listed regularly in $A B C$ Pol Sci and Current Contents: Behavioral, Social \& Management Sciences. Book reviews are indexed in Book Review Index. 


\title{
The American Political Science Review
}

\author{
Instructions to Contributors
}

Address correspondence about contributions to the Review to Dina A. Zinnes, American Political Science Review, Department of Political Science, University of Illinois at Urbana-Champaign, Urbana, Illinois 61801. Please submit five copies of a manuscript to be considered for publication. Unfortunate$l y$, due to increased postage costs, we can no longer return manuscripts to the author. Manuscripts must be typed on one side of the paper only and mimeographed or photocopies, with all written material double-spaced (including quotations, references, and footnotes). Use standard typewriter paper-avoid colored and light-weight stock. The typewritten lines should not exceed $5 \frac{1}{2}$ or 6 inches in length. Since manuscripts are sent out anonymously for evaluation, the author's name and affiliation should appear only on a separate covering sheet. An abstract of less than 150 words should accompany the manuscript. APSR will not consider articles submitted to other publications.

Beginning with the June 1983 issue, the reference form is that prescribed by the Publication Manual of the American Psychological Association, 2nd ed.; brief parenthetical references are included in the text and all sources are listed alphabetically at the end of the article. The work of classical authors such as Aristotle or Plato may be cited by the standardized code familiar to scholars in the field and passing allusions to such authors do not require mention in the list of references. Conventional foot-ofcolumn notes are used only for explanatory comments or in unusual cases to avoid lengthy in-text references.

Articles that draw on survey data not documented through the Inter-University Consortium for Political and Social Research should include the following information in an appendix: (1) a description of the population sampled, including definition of the geographical area covered, and details about how the sample was drawn sufficient to permit fairly exact replication; (2) response rate (for quota designs, the number of refusals); (3) exact question wordings; and (4) interviewer characteristics.

Manuscripts over 30 pages will be reviewed with particular care to determine if such length is warranted. Those over 50 pages will be returned to the author. Resubmission.may follow compliance with the page limit. Tables, charts, footnotes, and references will be included in the page count.

Figures should be professionally presented: use high-quality white paper and India ink for maximum sharpness and clarity of line. Copies only should accompany the submitted manuscript, original art work being retained until requested by the editorial office. Tables should be typed on separate pages, with guides, e.g., "Table 1 about here" at the proper places in the manuscript.

Communications must follow the form of regular manuscripts, including reference listings where appropriate. They must not exceed five double-spaced pages, including references, footnotes, and tables. All but the briefest letters will be refereed.

\section{Book Reviews}

Books intended for review and all book review correspondence should be sent to Seven Thomas Seitz, Book Review Editor, American Political Science Review, Department of Political Science, University of Illinois at Urbana-Champaign, Urbana, Illinois 61801. Authors are urged to call their books to the attention of the Book Review Editor to insure that the books will be considered for review. Those interested in reviewing books should submit a current vita.

\section{Other Correspondence}

Information, including News and Notes, for the Association's news-journal, PS, should be sent to 1527 New Hampshire Avenue, N.W., Washington, D.C. 20036. Advertising, reprint, and circulation correspondence should be sent to the Executive Director and the Washington office. Domestic claims for nonreceipt of issues must be made within four months of the month of publication; overseas claims, eight months. Advertising information and rates are available from Eloise French, Advertising Manager, APSA, 1527 New Hampshire Avenue, N.W., Washington, D.C. 20036. 


\section{The American}

Political Science

Association

-founded 1903

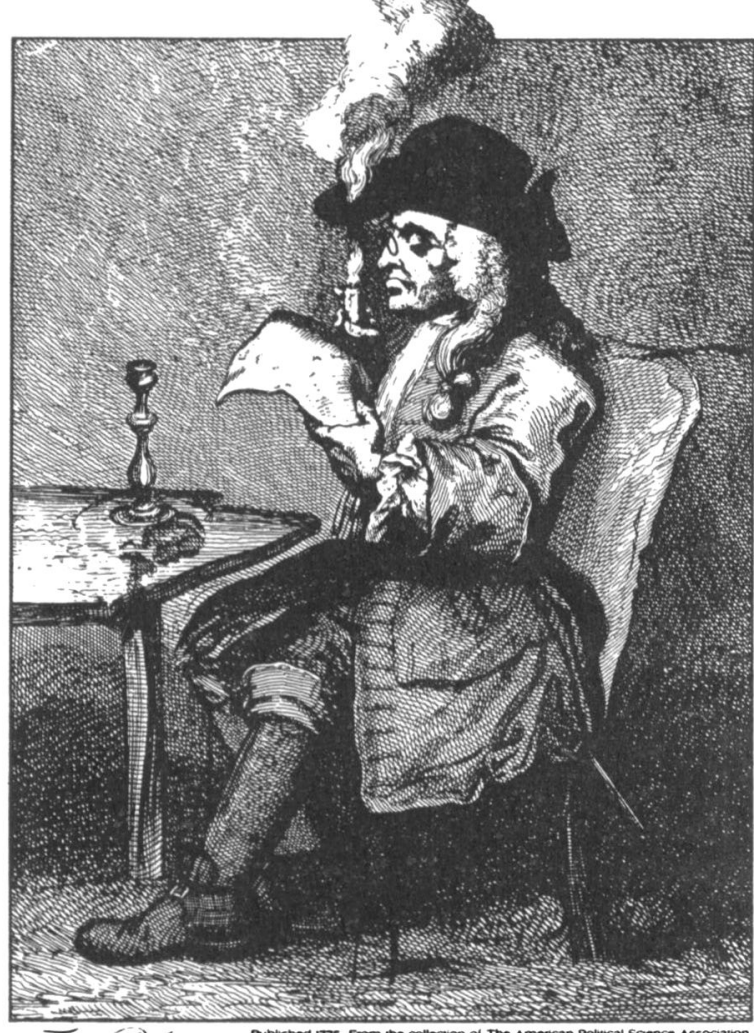

Why Join The APSA?

To become an active member of the profession.

The Association is the major professional organization for people engaged in the study of politics, with over 12.000 members.

To contribute to the advancement of the discipline and the profession.

The APSA lobbies for govern. ment support of political science research, promotes academic freedom. sponsors awards for scholarly excellence. develops teaching materials like SETUPS, and much more.

To receive these benefits: - Subscriptions to:

- The American Political

Science Review

-PS

-NEWS for Teachers of Political Science

- Discounts on subscriptions to over 50 other periodicals

- Lower Annual Meeting rates

- Group insurance plans

- Eligibility for employment services, including Personnel

Senvice Newsletter.

confidential credential

referrals, and more

- Membership in subfield Sections

To join APSA, please fill in and return the form below:

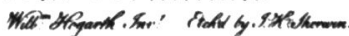

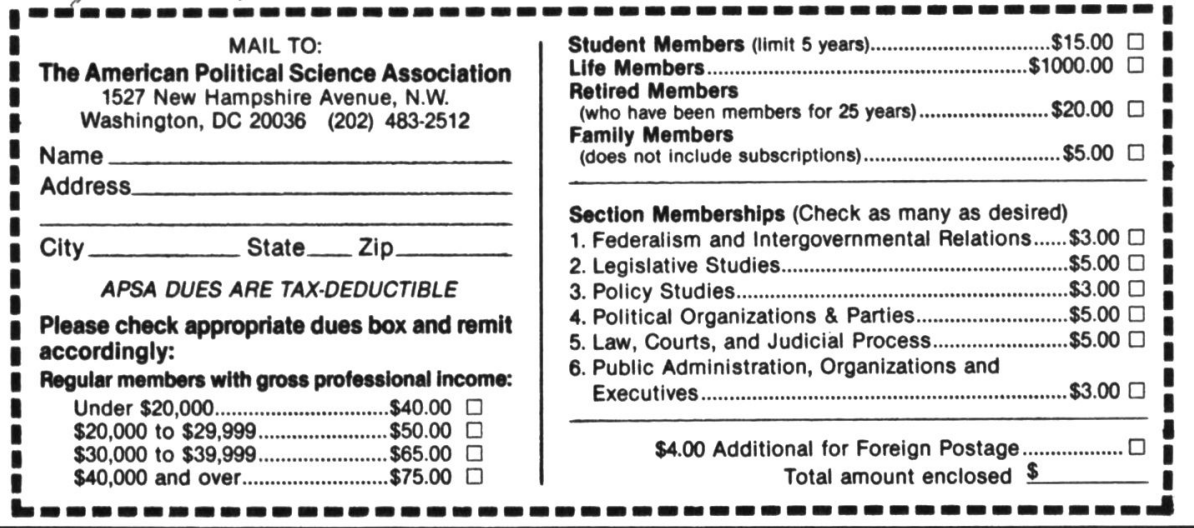

